
Annals of
Nutrition and
Metabolism

Ann Nutr Metab 2020;76(suppl 2):30-40

DOI: 10.1159/000505635
Received: December 4, 2019

Accepted: December 14, 2019

Published online: November 24, 2020

\title{
Vitamin D in Toddlers, Preschool Children, and Adolescents
}

\author{
Sarah N. Taylor \\ Department of Pediatrics, Yale School of Medicine, New Haven, CT, USA
}

\section{Key Messages}

- Vitamin D status is associated with avoidance of rickets and various autoimmune, infectious, and allergic diseases.

- Randomized, controlled trials of vitamin D supplementation for pediatric bone health are limited and equivocal in their results.

- The specific vitamin D supplementation to optimize toddler, child, and adolescent outcomes is unknown, but doses 10$50 \mu \mathrm{g} /$ day are safe and may be beneficial.

\section{Keywords}

Vitamins - Pediatrics - Bone disease - Calcium homeostasis Fractures · Vitamin D

\footnotetext{
Abstract

Background: Vitamin D supplementation is known to both prevent and treat rickets, a disease of hypomineralized bone. Childhood is a period of great bone development and, therefore, attention to the vitamin $D$ needed to optimize bone health in childhood is imperative. Summary: Observational studies have pointed to a vitamin D status, as indicated by a 25-hydroxyvitamin D concentration, of $50 \mathrm{nmol} / \mathrm{L}$ to ensure
}

avoidance of rickets and of $75 \mathrm{nmol} / \mathrm{L}$ to optimize health However, the benefits of achieving these levels of vitamin D status are less evident when pediatric randomized, controlled trials are performed. In fact, no specific pediatric vitamin D supplementation has been established by the existing evidence. Yet, study of vitamin D physiology continues to uncover further potential benefits to vitamin D sufficiency. This disconnection between vitamin D function and trials of supplementation has led to new paths of investigation, including establishment of the best method to measure vitamin D status, examination of genetic variation in vitamin D metabolism, and consideration that vitamin D status is a marker of another variable, such as physical activity, and its association with bone health. Nevertheless, vitamin D supplementation in the range of $10-50 \mu \mathrm{g} /$ day appears to be safe for children and remains a promising intervention that may yet be supported by clinical trials as a method to optimize pediatric health. Key Message: Pediatric vitamin D status is associated with avoidance of rickets. Randomized, controlled trials of vitamin D supplementation for pediatric bone health are limited and equivocal in their results. Beyond bone, decreased risk for autoimmune, infectious, and allergic diseases has been associated with higher vitamin D status. The specific vitamin D supplementation to optimize toddler, child, and adolescent outcomes is unknown, but doses $10-50 \mu \mathrm{g} /$ day are safe and may be beneficial.

(c) 2020 S. Karger AG, Basel karger@karger.com

www.karger.com/anm

(ㄷ) 2020 S. Karger AG, Basel

\section{Karger ${ }^{\prime} \div$}

Sarah N. Taylor

Department of Pediatrics

Yale School of Medicine, PO Box 208064

New Haven, CT 06520-8064 (USA)

sarah.n.taylor a yale.edu 


\section{Introduction}

Vitamin D deficiency rickets was a disease pervasive in children during the Industrial Revolution and prevented with one spoonful of cod liver oil. The disease dissipated in the pediatric population with improved living conditions, including sunlight exposure, and the addition of vitamin D fortification to food products. Through the 20th century, only a small number of studies investigated the vitamin $D$ supplementation required to maintain health in general populations. Lack of attention to vitamin D health status is evident by the 1989 United States Institute of Medicine (IOM) report which recommended $5 \mathrm{\mu g} /$ day (200 IU/day) for adults because this represented half the dose recommended to infants and was considered a "generous allowance" of supplementation [1]. The $10 \mathrm{\mu g} /$ day dose recommended to infants was based on the amount of vitamin $D$ in a spoonful of cod liver oil that prevented rickets and demonstrated how the scientific understanding of vitamin $\mathrm{D}$ physiology remained limited even in 1989.

However, in the 1990s, a resurgence in infant vitamin D deficiency rickets was described worldwide. These cases occurred in various populations but concentrated in those with less exposure to sunlight (i.e., high latitude especially in winter months), those with darker skin pigmentation, or those practicing complete covering of women and were often associated with breastfeeding. Despite this small but significant rise in prevalence, the IOM in 1997 decreased their recommendation of vitamin $D$ supplementation from 10 to $5 \mu$ g/day due to studies demonstrating that this dose provided adequate vitamin $D$ to achieve a 25 -hydroxyvitamin $D(25[\mathrm{OH}] \mathrm{D})$ status of $27.5 \mathrm{nmol} / \mathrm{L}(11 \mathrm{ng} / \mathrm{mL})$, which was thought to prevent rickets in "most" populations [1]. Remarkably, despite increasing reports of rickets, the American Academy of Pediatrics (AAP) chose to uphold the 1997 IOM recommendation and decreased their recommendation from 400 to 200 IU/day for all infants, children, and adolescents [2].

Therefore, the early 21st century marked a period of discord in vitamin D public health; as reports of disease escalated, public policy paradoxically decreased the recommended supplementation, and, finally, research in adult populations launched the identification of the vitamin $D$ status, $25(\mathrm{OH}) \mathrm{D}$ status, associated with optimal health outcomes. These investigations into the vitamin D status needed to optimize vitamin $D$ function were greatly needed because the previous recommended 25(OH)D concentration of 27.5 $\mathrm{nmol} / \mathrm{L}(11 \mathrm{ng} / \mathrm{mL})$ was based on an observational study of $25(\mathrm{OH}) \mathrm{D}$ status in 3 adult cohorts. The vitamin D status in a cohort of "healthy" adult volunteers was compared to status in a cohort of lifeguards (high sunlight exposure) and to status in a cohort of subjects with biliary cirrhosis who were assumed to have difficulty with conversion of vitamin $D$ to $25(\mathrm{OH}) \mathrm{D}$ in the liver. From these measurements, a bell curve of $25(\mathrm{OH}) \mathrm{D}$ status was developed with the status of lifeguards deemed the highest of "normal," the healthy volunteers deemed "normal," and the biliary cirrhosis patients deemed "low" [3]. This study and others ignored the potential issue that "healthy volunteers" were exhibiting insufficient or deficient vitamin $\mathrm{D}$.

\section{The early 21st century marked a period of discord in vitamin $D$ public health; as reports of disease escalated, public policy paradoxically decreased the recommended supplementation}

In the early 21st century, several investigators challenged this existing definition of normal when they performed studies to identify the vitamin D status required to optimize intestinal calcium absorption, to appropriately lower parathyroid hormone (PTH) concentration, and to optimize bone mineralization [4-6]. In these studies of vitamin $D$ function in the adult population, results pointed to $75-100 \mathrm{nmol} / \mathrm{L}$ as the lower limit of vitamin D sufficiency for adult calcium homeostasis and bone health. These studies and others led to new public health recommendations that include not only a definition of vitamin $D$ deficiency but also a definition of vitamin $D$ sufficiency (Table 1) [7-11]. In 2008, the AAP reevaluated its 2003 statement and chose to increase to a recommendation of at least $400 \mathrm{IU} /$ day for all infants, children, and adolescents [9].

Additionally, in the early 21st century, there were reports of vitamin D's potential role in disease processes not related to calcium homeostasis and bone health. Many organs have $25(\mathrm{OH}) \mathrm{D}$ receptors which bind $25(\mathrm{OH}) \mathrm{D}$. Instead of relying on the renal production of 1,25 -dihydroxyvitamin $\mathrm{D}\left(1,25[\mathrm{OH}]_{2} \mathrm{D}\right)$ from $25(\mathrm{OH}) \mathrm{D}$, these organs form $1,25(\mathrm{OH})_{2} \mathrm{D}$ locally in a paracrine fashion (Fig. 1). Therefore, these organs depend on the availability of vitamin $\mathrm{D}$ and its transformation to $25(\mathrm{OH}) \mathrm{D}$ by the liver to provide circulating $25(\mathrm{OH}) \mathrm{D}$. Disease processes in adults found to have an association with vitamin D status include cancer, specifically breast, colon, and prostate; heart 
Table 1. Public health recommendations for vitamin D status [7-11]

\begin{tabular}{lll}
\hline Organization & $\begin{array}{l}\text { Deficiency, } \\
\text { nmol/L 25(OH)D }\end{array}$ & $\begin{array}{l}\text { Sufficiency, } \\
\mathrm{nmol} / \mathrm{L} 25(\mathrm{OH}) \mathrm{D}\end{array}$ \\
\hline Institute of Medicine [7] & $<30$ & $>50$ \\
American Academy of Pediatrics [9] & $<50$ & $<50$ \\
Endocrine Society [10] & $<25$ severe deficiency & $>50$ \\
European Society for Paediatric Gastroenterology, Hepatology and Nutrition [8] & $<25$ severe deficiency & $>50$ \\
European Calcified Tissue Society [11] & $<50$ deficiency & \\
\hline
\end{tabular}

disease; autoimmune disease, specifically diabetes, rheumatoid arthritis, and systemic lupus erythematosus; infectious disease, specifically influenza and tuberculosis; and allergic disease [12]. Not all associations have been substantiated by further investigation such as trials of vitamin D supplementation. However, they have led to exploration of similar associations in children and adolescents, which thereby are considerations in vitamin D supplementation to these age groups.

Specifically, for toddlers, children, and adolescents, the significance of vitamin D supplementation in bone health is of paramount importance during this critical time of skeletal development. Especially in lower-resource countries where calcium deficiency also is widespread, supplementation of both nutrients is required to avoid bone disease. Additionally, determining the evidence regarding the role of vitamin $D$ in autoimmune, allergic, and infectious disease is critical to ensure disease risk is minimized for all children.

\section{Prevalence of Vitamin D Deficiency and Insufficiency}

Studies vary in reports of vitamin D deficiency and insufficiency worldwide. A snapshot of large population studies is provided in Table 2 to demonstrate the trends through the years, differences and similarities between countries, and variation between age groups. Studies performed in Asia demonstrate a higher prevalence of vitamin $D$ deficiency compared to those in Europe, North America, and New Zealand [13-22]. However, one Western population observed to have a higher prevalence are adolescents in the Public Health England database where $20 \%$ of boys $11-18$ years old and $24 \%$ of girls 11-18 years old demonstrated a $25(\mathrm{OH}) \mathrm{D}$ level $<25 \mathrm{nmol} / \mathrm{L}$ [18]. In fact, though infants are at risk for disease such as vitamin D-associated rickets worldwide, many population studies in higher-resource countries demonstrate lower vitamin D
Vitamin $D$ produced from exposure to ultraviolet $B$ light (290-315 nm) or ingested

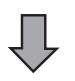

25-hydroxyvitamin $D$ formed in liver

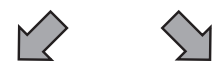

1,25-dihyroxyvitamin $D$ formed in kidney with hormonal activity at small intestine, bone, and kidney

1,25-dihyroxyvitamin $D$ formed in brain, heart, pancreas, skin, gonads, prostate, breast, and gut with local paracrine activity at each individual organ

Fig. 1. Production of active vitamin D in humans.

status in adolescents compared to toddlers [15, 16, 18], while studies in lower-resource countries show the expected higher vitamin D deficiency prevalence for infants/toddlers especially when breastfeeding [21]. Dark skin color, measured by race, ethnicity, or skin pigmentation, is a risk factor for deficient vitamin $D[13,15,19,22]$. In countries where milk and/or juice are fortified with vitamin D, lower or no intake of these products is associated with higher risk for deficiency, which supports fortification as a method to improve child vitamin D status $[13,15,19]$.

Other populations at increased risk for vitamin $\mathrm{D}$ deficiency include immigrant/refugee children moving to higher-latitude countries [23, 24], children with chronic disease that decreases fat absorption, children receiving anti-epileptic medications, and obese children [25-27]. For children with diseases with impaired fat absorption, such as cystic fibrosis, higher supplementation of this fat-soluble vitamin likely is required [25]. For children on anti-epileptic medications, these medications are known to upregulate enzymes involved in 
Table 2. Prevalence and risk factors for vitamin D deficiency in pediatric (non-infant) populations worldwide

\begin{tabular}{|c|c|c|c|}
\hline Study & Population & $\begin{array}{l}\text { Vitamin D deficiency } \\
\text { prevalence }(25[\mathrm{OH}] \mathrm{D})\end{array}$ & Identified risk factors for deficiency \\
\hline Gordon et al. [13], 2004 & $\begin{array}{l}307 \text { adolescents ( } 11-18 \text { years } \\
\text { old) in Boston, MA, USA }\end{array}$ & $\begin{array}{l}\leq 20 \mathrm{nmol} / \mathrm{L}: 4.6 \% \\
\leq 37.5 \mathrm{nmol} / \mathrm{L}: 24.1 \% \\
\leq 50 \mathrm{nmol} / \mathrm{L}: 42 \%\end{array}$ & $\begin{array}{l}\text { Season, ethnicity, low milk and juice } \\
\text { consumption, low body mass index, low } \\
\text { physical activity }\end{array}$ \\
\hline Marwaha et al. [14], 2005 & $\begin{array}{l}5,13710 \text { - to } 18 \text {-year-olds in } \\
\text { New Delhi, India }\end{array}$ & $<22.5 \mathrm{nmol} / \mathrm{L}: 35.7 \%$ & Lower socioeconomic school, female \\
\hline Kumar et al. [15], 2009 & $\begin{array}{l}6,275 \text { children } 1-21 \text { years old } \\
\text { in USA, 2001-2004 }\end{array}$ & $\begin{array}{l}<37.5 \mathrm{nmol} / \mathrm{L}: 9 \% \\
<72.5 \mathrm{nmol} / \mathrm{L}: 70 \%\end{array}$ & $\begin{array}{l}\text { Older, female, non-Hispanic black, } \\
\text { Mexican-American, obese, milk < once/ } \\
\text { week, }>4 \text { h screen time }\end{array}$ \\
\hline Rabenberg et al. [16], 2018 & $\begin{array}{l}\text { 10,015 children } 1-17 \text { years old } \\
\text { in Germany, 2003-2006 }\end{array}$ & $\begin{array}{l}<30 \mathrm{nmol} / \mathrm{L}: 12.5 \% \text { in both } \\
\text { boys and girls } \\
30 \text { to }<50 \mathrm{nmol} / \mathrm{L}: 32.7 \% \text { in } \\
\text { boys and } 33.5 \% \text { in girls }\end{array}$ & $\begin{array}{l}\text { Highest prevalence of deficiency in girls } \\
11-13 \text { years old (18.9\%) and lowest } \\
\text { prevalence of deficiency in boys } 1-2 \text { years } \\
\text { old }(4.9 \%)\end{array}$ \\
\hline Foo et al. [17], 2009 & $\begin{array}{l}301 \text { adolescents (15-year-old } \\
\text { girls) in Beijing, China, } 2004\end{array}$ & $\begin{array}{l}<25 \mathrm{nmol} / \mathrm{L}: 31.2 \% \\
\leq 50 \mathrm{nmol} / \mathrm{L}: 57.8 \%\end{array}$ & Not provided \\
\hline $\begin{array}{l}\text { Public Health England, } \\
\text { National Diet and Nutrition } \\
\text { Survey [18], } 2014\end{array}$ & $\begin{array}{l}902 \text { children in the } \\
\text { United Kingdom, 2008-2011 }\end{array}$ & $\begin{array}{l}<25 \mathrm{nmol} / \mathrm{L}: 8 \% \text { of children } \\
1.5-3 \text { years old, } 12 \% \text { of boys } \\
4-10 \text { years old, } 16 \% \text { of girls } \\
4-10 \text { years old, } 20 \% \text { of boys } \\
11-18 \text { years old, } 24 \% \text { of girls } \\
11-18 \text { years old }\end{array}$ & Not provided \\
\hline Maguire et al. [19], 2013 & $\begin{array}{l}1,898 \text { children ( } 1-5 \text { years old) } \\
\text { in Toronto, ON, Canada }\end{array}$ & $\begin{array}{l}<50 \mathrm{nmol} / \mathrm{L}: 6 \% \\
<75 \mathrm{nmol} / \mathrm{L}: 35 \%\end{array}$ & $\begin{array}{l}\text { No vitamin D supplement, no cow's milk } \\
\text { intake, winter season, dark skin } \\
\text { pigmentation }\end{array}$ \\
\hline Garg et al. [20], 2014 & $\begin{array}{l}1,829 \text { adolescents in } \\
\text { New Delhi, India }\end{array}$ & $\begin{array}{l}<12.5 \mathrm{nmol} / \mathrm{L}: 28 \% \\
<25 \mathrm{nmol} / \mathrm{L}: 71 \% \\
<50 \mathrm{nmol} / \mathrm{L}: 97 \%\end{array}$ & Not provided \\
\hline Angurana et al. [21], 2014 & $\begin{array}{l}388 \text { children ( } 3 \text { months to } \\
12 \text { years) in Chandigarh, India }\end{array}$ & $\begin{array}{l}<50 \mathrm{nmol} / \mathrm{L}: 40 \% \\
<75 \mathrm{nmol} / \mathrm{L}: 66 \%\end{array}$ & $\begin{array}{l}\text { Younger age, female, failure to thrive, } \\
\text { exclusive breastfeeding, inadequate sun } \\
\text { exposure, and no vitamin D supplements }\end{array}$ \\
\hline Cairncross et al. [22], 2017 & $\begin{array}{l}1,329 \text { children ( } 2 \text { to }<5 \text { years) } \\
\text { in New Zealand }\end{array}$ & $\begin{array}{l}<25 \mathrm{nmol} / \mathrm{L}: 7 \% \\
<50 \mathrm{nmol} / \mathrm{L}: 48 \% \\
<75 \mathrm{nmol} / \mathrm{L}: 89 \%\end{array}$ & $\begin{array}{l}\text { Female gender, other non-European } \\
\text { ethnicities (not including Māori or Pacific), } \\
\text { had olive-dark skin color, no vitamin D } \\
\text { supplements, mothers with less than } \\
\text { secondary school qualifications, and lived } \\
\text { in more deprived households }\end{array}$ \\
\hline
\end{tabular}

25(OH)D, 25-hydroxyvitamin D.

vitamin D metabolite inactivation. Therefore, higher supplementation is also a consideration in this population [26].

For obese children, a significant inverse association between vitamin D status and overweight status was identified as early as 15-23 months of age [28]. Due to this association, increased vitamin D supplementation often is recommended in the presence of overweight or obesity. Also, an additional benefit for achieving vitamin D sufficiency may be improved carbohydrate and lipid metabolism [27].

Vitamin D in Children
A potential risk factor for vitamin D deficiency that is often associated with obesity and requires further study is low physical activity [13]. Since physical activity in children commonly occurs with sunlight exposure, physical activity may be a surrogate for sunlight exposure and, therefore, indirectly associated with vitamin D status. On the other hand, physical activity may confound studies of vitamin D sufficiency due to physical activity's positive association with bone health. In this scenario, increased physical activity would be associated with 
increased sun exposure and, thereby, increased vitamin D status. This raises the theory that vitamin D status may serve as a marker of physical activity instead of serving as a cause of improved bone health. With persistent questions regarding the vitamin D supplementation that provides optimal bone health, these potential causal relationships warrant contemplation and investigation [29-32].

\section{Vitamin D in Pediatric Bone Health}

The primary function of vitamin D is to maintain calcium homeostasis and bone health. The most severe form of vitamin $\mathrm{D}$-associated bone disease is rickets. Rickets occurs when hypocalcemia and/or hypophosphatemia affect development of the epiphyseal growth plate and is most common in infancy. Signs and symptoms associated with rickets include skeletal findings of leg bowing, knock knees, rachitic rosary, and nonskeletal findings, such as muscle weakness, seizures, tetany, and cardiomyopathy. These signs and symptoms, especially the radiographic finding of cupping, fraying, and splaying of metaphyses near the epiphyseal growth plate, are diagnostic of rickets.

Muscle weakness or muscular pain often are described in relation to vitamin D deficiency-associated bone disease [11, $29,30]$. In fact, perhaps rickets and osteomalacia should be described as musculoskeletal rather than only skeletal diseases. Osteomalacia is a disease of hypomineralization that may or may not have the pathognomonic cupping of the metaphyses. Osteomalacia occurs when the osteoblasts develop the osteoid but with inadequate mineral deposition due to deficiency in calcium and/or phosphorus. If this disease of demineralized bone does not affect the epiphyseal growth plate either due to lower severity or to the phase of bone growth, then rickets is not diagnosed by radiograph. However, significant skeletal disease may have occurred. This is of special concern in childhood because of the high rate of bone growth. Ninety percent of adult bone mineralization is accrued by the end of adolescence. Furthermore, vitamin D status in adolescence may be paramount because $40 \%$ of adult bone mineralization occurs within this time of peak bone growth velocity $[29,33]$.

Therefore, with the relatively high prevalence of vitamin $D$ deficiency described in the pediatric population and the known importance of calcium in bone mineralization during this critical time of growth, evaluation of bone outcomes with vitamin D supplementation is of paramount importance. Randomized, controlled trials of vitamin D supplementation to optimize bone health have been performed in adolescents and mostly in females (Table 3) [34-42]. Two meta-analyses of 6 of the randomized, controlled trials were published in 2010 and 2011 by the same authors in 2 different journals [43, $44]$. Both meta-analyses concluded that vitamin D supplementation demonstrated no significant effect on total body bone mineral content (BMC) or bone mineral density of the hip or forearm [43,44]. The 4 randomized, controlled trials in children, published after the meta-analyses were performed, demonstrate a range of results. The results of one study showed no significant effect of vitamin D supplementation [42]. In a second study, total body and lumbar spine BMC were improved with vitamin D supplementation in a subgroup of girls who were $<2$ years past menarche [40]. In a third study, girls exhibited significantly improved bone density especially in measures of bone parameters in the hip, but boys did not [39]. In a fourth study, whole body BMC and density were increased not in the whole group but in a subgroup of children expressing the FF vitamin D receptor genotype [41]. These studies raise the importance of the need for a further understanding of vitamin D physiology so that vitamin D supplementation trials are performed in the populations of greatest need either due to baseline vitamin D deficiency, sex, age, and stage of bone development or genetic predisposition to higher vitamin $D$ needs for healthy bone development. Of the studies showing benefit of supplementation, the supplementation was given as either 5-10 $\mu \mathrm{g} /$ day or 35-350 $\mu \mathrm{g} /$ week of vitamin $D_{3}$. With the low risk of toxicity with these vitamin $D$ doses, at least these amounts of supplementation may be of benefit and have very low risk of harm. However, despite conduction of 10 randomized, controlled trials in adolescent girls, the definitive amount of vitamin D supplementation associated with optimal bone mineralization remains unknown, and less is known regarding boys' needs.

Even fewer studies of high-level evidence have been performed in the toddler and younger child populations. Instead of supplementation trials, evaluation of the vitamin D status associated with bone health provides the available evidence. For example, in a large study in Korea, 429 boys 10-14 years of age demonstrated a significant association between vitamin D status and bone mineralization at the femoral neck, hip, and lumbar spine. Girls aged 10-13 years only demonstrated a significant association at the lumbar spine. In the larger population of this study, including older adolescents and adults up to 29 years, bone mineralization appeared to have a nonlinear association with vitamin $\mathrm{D}$ status with optimal bone outcomes with 25(OH)D $>53 \mathrm{nmol} / \mathrm{L}$ [45].

Other studies have evaluated PTH concentrations as a direct marker of body calcium homeostasis and as an indirect marker of bone health. In observational studies, a linear correlation between $25(\mathrm{OH}) \mathrm{D}$ and $\mathrm{PTH}$ often is significant and with a correlation coefficient of -0.2 to $-0.3[13,14]$. When 
Table 3. Randomized controlled trials of vitamin D supplementation to adolescents

\begin{tabular}{|c|c|c|c|}
\hline Study & Population & Intervention & Bone outcome measurements \\
\hline $\begin{array}{l}\text { Andersen et al. [34], } \\
2008\end{array}$ & $\begin{array}{l}26 \text { female Pakistani immigrants to } \\
\text { Denmark at } 10.1-14.7 \text { years old }\end{array}$ & $\begin{array}{l}\text { Vitamin } D_{3} 10 \text { or } 20 \mu \mathrm{g} / \text { day for } \\
12 \text { months compared to placebo }\end{array}$ & $\begin{array}{l}\text { DXA measurements of the whole } \\
\text { body and lumbar spine }\end{array}$ \\
\hline Cheng et al. [35], 2005 & $\begin{array}{l}195 \text { girls } 10-12 \text { years old in Finland } \\
\text { with <900 mg daily calcium intake }\end{array}$ & $\begin{array}{l}\text { Calcium and } 5 \mu \mathrm{g} / \text { day vitamin } \\
\mathrm{D}_{3} \text { or calcium or cheese or } \\
\text { placebo for } 2 \text { years }\end{array}$ & $\begin{array}{l}\text { Whole body DXA with indexes at the } \\
\text { hip, spine, and peripheral quantitative } \\
\text { computed tomography of the radius } \\
\text { and tibia }\end{array}$ \\
\hline $\begin{array}{l}\text { El-Hajj Fuleihan et al. } \\
\text { [37], } 2006\end{array}$ & $\begin{array}{l}179 \text { girls at } 10-17 \text { years old in Beirut, } \\
\text { Lebanon }\end{array}$ & $\begin{array}{l}\text { Vitamin } D_{3} 35 \text { or } 350 \mu \mathrm{g} / \text { week } \\
\text { or placebo for } 1 \text { year }\end{array}$ & $\begin{array}{l}\text { DXA of lumbar spine, hip, forearm, } \\
\text { and total body }\end{array}$ \\
\hline $\begin{array}{l}\text { Khadilkar et al. [40], } \\
2010\end{array}$ & $\begin{array}{l}50 \text { postmenarchal girls at } 14-15 \text { years } \\
\text { old in Pune, India }\end{array}$ & 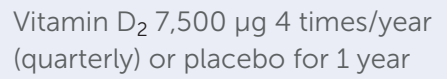 & DXA of full body and lumbar spine \\
\hline $\begin{array}{l}\text { Mølgaard et al. [41], } \\
2010\end{array}$ & 221 girls $11-12$ years old in Denmark & $\begin{array}{l}\text { Vitamin } D_{3} 5 \text { or } 10 \mu \mathrm{g} / \text { day or } \\
\text { placebo }\end{array}$ & DXA of full body and lumbar spine \\
\hline Ward et al. [42], 2010 & 73 postmenarchal girls $12-14$ years old & 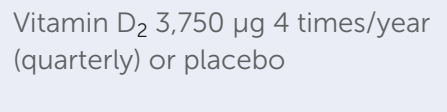 & $\begin{array}{l}\text { DXA of lumbar spine and peripheral } \\
\text { quantitative computed tomography } \\
\text { of nondominant radius and tibia }\end{array}$ \\
\hline
\end{tabular}

One $\mu \mathrm{g}$ vitamin D is $40 \mathrm{IU}$ vitamin D. DXA, dual energy X-ray absorptiometry.

examining 25(OH)D status and PTH status with nonlinear or multi-linear statistical approaches, an inflection point, a 25(OH)D value below which PTH decreases with increasing 25(OH)D concentration and above which PTH plateaus despite rising $25(\mathrm{OH}) \mathrm{D}$, may be identified. This inflection point is hypothesized to be the $25(\mathrm{OH}) \mathrm{D}$ limit associated with PTH stability and, therefore, calcium homeostasis. In a sample of children aged 6-10 years, a 25(OH)D status above $75 \mathrm{nmol} / \mathrm{L}$ was associated with a plateau in PTH concentration, and a 25(OH)D status below $50 \mathrm{nmol} / \mathrm{L}$ was associated with a significant rise in PTH [46]. A study of children aged 12-22 months identified an inflection point of $60-65 \mathrm{nmol} / \mathrm{L} 25(\mathrm{OH})$ D [47]. In an evaluation of 214 children of whom 17 were diagnosed with rickets, an inflection point was evident at 34 $\mathrm{nmol} / \mathrm{L}$ [48]. Yet, this inverse association or identification of an inflection point is not universally found in studies comparing 25(OH)D and PTH status. Consequently, further investigation is needed. Similarly, studies of an association between vitamin
D status and other markers of calcium homeostasis and/or bone health have yielded equivocal results. Researchers in this area are working to identify a compilation of serum measurements that would predict the development of osteomalacia, but these tests require validation [49].

Another area of potential consequence of hypovitaminosis $\mathrm{D}$ in pediatric bone health is the risk for fracture. One crosssectional study and 2 case-controls have examined this potential association of vitamin $D$ deficiency and increased risk for fracture in children [50-52]. In a cross-sectional study of 10 - to 16-year-old children, those with upper limb fracture, lower limb fracture, and no fracture demonstrated no significant difference in 25(OH)D status [50]. In a case-control study of 5- to 9-year-old African American children, compared to the 74 controls, the 76 cases exhibited 3.64 (95\% Cl 1.0910.94) higher odds of vitamin D deficiency [51]. However, in a second case-control study in Canada of children $<6$ years of age, compared to the 343 controls, the 206 cases had no dif- 
ferences in vitamin D status or intake of cow's milk. Yet, use of vitamin D supplementation was associated with decreased odds of fracture (adjusted odds ratio of 0.42 [95\% $\mathrm{Cl} 0.25-$ 0.69]) [52].

Another approach to evaluate the relationship between vitamin D deficiency and fractures was published recently. In this study of children under 2 years of age who were admitted with fractures, 11 of 79 demonstrated hypomineralization on skeletal survey. For every 10 -point increase in vitamin D status, the adjusted odds of hypomineralization were reduced 0.3 (95\% Cl 0.17-0.82) [53]. This limited data of the association of vitamin D, osteomalacia, and fracture risk requires further exploration especially for populations at higher risk for vitamin D deficiency.

Expedient exploration of this relationship is crucial due to considerable debate in the literature as to whether fractures due to osteomalacia/rickets can be differentiated from fractures due to nonaccidental trauma by X-ray or laboratory markers [54-57]. Currently, published literature points to the consideration of bone biopsy as a method to detect hypomineralization disease versus child abuse. Further investigation to reliably differentiate the cause of fractures will provide further knowledge regarding osteomalacia and how this disease affects bone strength and development.

\section{Vitamin D in Non-Bone-Related Disease}

As in the adult population, in children, vitamin D has actions in health beyond calcium homeostasis and bone development. Greater detail regarding non-bone-related effects of vitamin $D$ is provided in a separate article in this issue, but these potential effects are important to mention as they do affect recommendations for vitamin $\mathrm{D}$ supplementation. The role of vitamin $D$ in both protection from development of type I diabetes mellitus and in improved glucose tolerance has been described with meta-analyses of vitamin D supplementation of observational trials [58]. Further randomized, controlled trials and investigation as to whether vitamin D improves $\beta$-cell function directly or through its beneficial effect on immune function are warranted. Children with allergic disease, especially asthma and atopic dermatitis, experience decreased exacerbations with vitamin D supplementation [31, $59,60]$. Infectious diseases with high incidence in childhood, such as otitis media, urinary tract infection, pneumonia, influenza, and other acute respiratory infections, all have a number of investigations demonstrating decreased incidence with higher vitamin D status [12]. Several randomized, controlled trials of vitamin D supplementation to prevent infections have been performed with equivocal results $[12,61,62]$. Therefore, these roles of vitamin D in health promotion warrant consideration but require further study before definitive supplementation recommendations.

\section{Children with allergic disease, especially asthma and atopic dermatitis, experience decreased exacerbations with vitamin D supplementation}

\section{Recommendations for Vitamin D Status}

Several international and national guidelines for categorization of vitamin D status are presented in Table 1. Of note, only 2 recommendations are specifically for children. Circulating $25(\mathrm{OH}) \mathrm{D}$ is the best indicator of nutritional vitamin $\mathrm{D}$ status due to its half-life of 2-3 weeks and to its mechanism of action in numerous organ systems. Nonetheless, 25(OH)D status does not consistently increase as expected with vitamin D dosing, which has raised the question as to what further considerations should be taken in the identification of healthy or unhealthy vitamin D status. For example, antibody-based methods of $25(\mathrm{OH}) \mathrm{D}$ that are readily available for use in various settings demonstrate less reproducibility when compared to liquid chromatography-mass spectroscopy (LCMS). On the other hand, LCMS is not universally available, and excellent antibody-based methods do exist [63]. Other issues in the analysis of $25(\mathrm{OH}) \mathrm{D}$ status include the potential that free $25(\mathrm{OH}) \mathrm{D}$ is a more important measurement than total $25(\mathrm{OH})$ $\mathrm{D}$ due to population variation in vitamin D-binding protein affinities. Lastly, individual variation in response to vitamin $D$ supplementation may be due to genetic differences in the vitamin D receptor [64]. Until these issues are elucidated, the interpretation of vitamin D study results remains with some uncertainty. In fact, the European Calcified Tissue Society has called for standardization of testing for all research of vitamin D status to improve consistency [11]. In the clinical setting, no guidelines are available to recommend specific vitamin D status screening in routine pediatric care partly because of this ambiguity in 25(OH)D test results $[7,65,66]$. Therefore, emphasis should be placed on providing the vitamin D supplementation to optimize health and to avoid toxicity for all children without the need for individual screening. 


\section{Recommended Vitamin D Intake for Toddlers, Children, and Adolescents}

In 2008, in response to the growing evidence of vitamin D deficiency in children, the AAP recommended at least $10 \mu \mathrm{g} /$ day vitamin D for all children [9]. In 2010, the IOM recommended at least $15 \mu \mathrm{g} /$ day for children over 1 year of age [7]. In Europe, ESPGHAN recommended $10 \mu \mathrm{g} /$ day for infants but chose not to provide recommendations for older children. Instead, they endorsed the European Food Safety Authority's upper limit of recommended intake of $25 \mu \mathrm{g} /$ day for infants, $50 \mu \mathrm{g} /$ day for children $1-10$ years, and $100 \mu \mathrm{g} /$ day for children 11-17 years [8]. Recently, new recommendations in Europe, and specifically in Germany, have continued to emphasize the need for vitamin D supplementation to infants, have added recommendations for pregnant women, but have decreased the recommendations for older children and adolescents due to the equivocal results of randomized, controlled trials of vitamin D supplementation and due to the difficulties in interpretation of vitamin D status $[11,31]$. Of note, the higher risk for vitamin $D$ deficiency in non-Western or immigrant populations of Europe remains a concern with recommendation to consider $10 \mu \mathrm{g} /$ day supplementation [11].

Recommendation for supplementation to children aged 1-3 years is quite varied in these new recommendations. These children, especially if not receiving fortified food products, remain at risk for inadequate bone mineralization. They also are a population found to have persistently low vitamin D intake despite existing recommendations. In France, in children who received vitamin $D$ from food sources and supplementation, $10 \%$ of infants $30-35$ months of age still received less than the recommended intake [67]. In the USA, despite attention to vitamin $\mathrm{D}$ supplementation in the last 2 decades, a greater number of children 0-47.9 months of age received less than the recommended supplementation in 2016 compared to 2002 [68]. In the United Kingdom, just over half of parents reported receiving information regarding vitamin $D$ supplementation for their infant and $80 \%$ described that they found the information lacking adequate details [69]. Therefore, for toddlers and children, not only are the recommendations varied, but so are vitamin D intake and parental knowledge regarding child vitamin $D$ needs.

When contemplating the appropriate intake of vitamin D, the potential for toxicity must be considered. Though the $25(\mathrm{OH}) \mathrm{D}$ concentration at which harm occurs is likely well above the therapeutic range, intoxication due to misadministration or accidental ingestion is reported to occur with doses of 6,000-112,500 $\mu \mathrm{g}$ and result in severe hypercalcemia. The literature contains one case report of vitamin D intoxication in a 7-month-old receiving 35-40 $\mu \mathrm{g} /$ day [70]. Therefore, overdose is a rare but potential risk. Parental education regarding safe administration is required.

\section{Conclusion}

As the amount of research investigating the vitamin $D$ needs of toddlers, children, and adolescents has grown, unfortunately, the answer has become less clear. Vitamin D-deficient rickets is a disease with severe morbidity that responds well to vitamin $D$ repletion. This disease is most common in infants but can be observed in children especially in resource-limited countries. Osteomalacia, or bone hypomineralization not of the magnitude of rickets, is more difficult to diagnose and, therefore, study of its response to vitamin D supplementation is challenging. Observational studies in pediatrics point to at least $10 \mu \mathrm{g} /$ day vitamin D supplementation to achieve optimal bone health, but results of randomized, controlled trials have been ambiguous. Vitamin D has been found to play a significant role in immune function and especially in autoimmune, infectious, and allergic disease, but again trials of vitamin D supplementation have been equivocal. Due to these study results and other issues, national and international guidelines are being modified to reflect this uncertainty and provide less directive regarding vitamin $\mathrm{D}$ supplementation after infancy. Attention to standard 25(OH)D concentration measurement and investigation of genetic or other individual variations in vitamin D metabolism hopefully will identify the cause of these discrepancies in research results. Until then, with the potential benefits and low risk of vitamin D supplementation of 10-50 $\mu \mathrm{g} /$ day for children, some physicians and public health leaders may elect to recommend these doses until further information is known.

\section{Disclosure Statement}

The writing of this article was supported by Nestle Nutrition Institute and the author declares no other conflict of interest.

\section{Funding Sources}

Dr. Sarah N. Taylor received National Institute of Health funding for research in vitamin D 2007-2012 and has served as a consultant for Alcresta Therapeutics. She has no funding source related to this manuscript.

\section{Author Contributions}

Dr. Sarah N. Taylor performed the literature review and wrote all aspects of this manuscript. 


\section{References}

1 Institute of Medicine (US) Standing Committee on the Scientific Evaluation of Dietary Reference Intakes. Dietary Reference Intakes for Calcium, Phosphorus, Magnesium, Vitamin D, and Fluoride. Washington (DC): National Academies Press (US); 1997. Available from: https://www.ncbi.nlm.nih.gov/books/NBK109825/

2 Gartner LM, Greer FR; Section on Breastfeeding and Committee on Nutrition. American Academy of Pediatrics. Prevention of rickets and vitamin $D$ deficiency: new guidelines for vitamin $D$ intake. Pediatrics. 2003 Apr;111(4 Pt 1):908-10.

3 Haddad JG, Chyu KJ. Competitive protein-binding radioassay for 25-hydroxycholecalciferol. J Clin Endocrinol Metab. 1971 Dec; 33(6):992-5.

4 Heaney RP, Dowell MS, Hale CA, Bendich A. Calcium absorption varies within the reference range for serum 25 -hydroxyvitamin $D$. J Am Coll Nutr. 2003 Apr;22(2):142-6.

5 Vieth R, Ladak Y, Walfish PG. Age-related changes in the 25-hydroxyvitamin $D$ versus parathyroid hormone relationship suggest a different reason why older adults require more vitamin D. J Clin Endocrinol Metab. 2003 Jan;88(1):185-91.

6 Bischoff-Ferrari HA, Dietrich T, Orav EJ, Dawson-Hughes B. Positive association between 25-hydroxy vitamin D levels and bone mineral density: a population-based study of younger and older adults. Am J Med. 2004 May;116(9):634-9.

7 Dietary Reference Intakes for Calcium and Vitamin D. Washington (DC): National Academy of Sciences; 2011.

8 Braegger C, Campoy C, Colomb V, Decsi T, Domellof M, Fewtrell $M$, et al.; ESPGHAN Committee on Nutrition. Vitamin D in the healthy European paediatric population. J Pediatr Gastroenterol Nutr. 2013 Jun;56(6):692-701.

9 Wagner CL, Greer FR; American Academy of Pediatrics Section on Breastfeeding; American Academy of Pediatrics Committee on Nutrition. Prevention of rickets and vitamin D deficiency in infants, children, and adolescents. Pediatrics. 2008 Nov;122(5):1142-52.

10 Holick MF, Binkley NC, Bischoff-Ferrari HA, Gordon CM, Hanley DA, Heaney RP, et al.; Endocrine Society. Evaluation, treatment, and prevention of vitamin D deficiency: an Endocrine Society clinical practice guideline. J Clin Endocrinol Metab. 2011 Jul;96(7): 1911-30.

11 Lips P, Cashman KD, Lamberg-Allardt C, Bischoff-Ferrari HA, Obermayer-Pietsch B, Bianchi ML, et al. Current vitamin D status in European and Middle East countries and strategies to prevent vitamin D deficiency; a position statement of the European Calcified Tissue Society. Eur J Endocrinol. 2019 Apr;180(4):P23-54.

12 Marino R, Misra M. Extra-skeletal effects of vitamin D. Nutrients. 2019 Jun;11(7):E1460.

13 Gordon CM, DePeter KC, Feldman HA, Grace E, Emans SJ. Prevalence of vitamin D deficiency among healthy adolescents. Arch Pediatr Adolesc Med. 2004 Jun;158(6):531-7.

14 Marwaha RK, Tandon N, Reddy DR, Aggarwal R, Singh R, Sawhney $R C$, et al. Vitamin $D$ and bone mineral density status of healthy schoolchildren in northern India. Am J Clin Nutr. 2005 Aug; 82(2): 477-82.
15 Kumar J, Muntner P, Kaskel FJ, Hailpern SM, Melamed ML. Prevalence and associations of 25-hydroxyvitamin D deficiency in US children: NHANES 2001-2004. Pediatrics. 2009 Sep;124(3):e36270 .

16 Rabenberg M, Scheidt-Nave C, Busch MA, Thamm M, Rieckmann $\mathrm{N}$, Durazo-Arvizu RA, et al. Implications of standardization of serum 25-hydroxyvitamin D data for the evaluation of vitamin D status in Germany, including a temporal analysis. BMC Public Health. 2018 Jul;18(1):845.

17 Foo LH, Zhang Q, Zhu K, Ma G, Trube A, Greenfield H, et al. Relationship between vitamin D status, body composition and physical exercise of adolescent girls in Beijing. Osteoporos Int. 2009 Mar;20(3):417-25.

18 Public Health England, Food Standards Agency. National Diet and Nutrition Survey: Results from Years 1, 2, 3 and 4 (combined) of the Rolling Programme (2008/2009-2011/2012). Secondary National Diet and Nutrition Survey Results from Years 1, 2, 3 and 4 (combined) of the Rolling Programme (2008/2009-2011/2012). London: Public Health England; 2014.

19 Maguire JL, Birken CS, Khovratovich M, Degroot J, Carsley S, Thorpe KE, et al.; TARGet Kids! Collaboration. Modifiable determinants of serum 25-hydroxyvitamin D status in early childhood: opportunities for prevention. JAMA Pediatr. 2013 Mar;167(3):2305.

20 Garg MK, Tandon N, Marwaha RK, Menon AS, Mahalle N. The relationship between serum 25-hydroxy vitamin D, parathormone and bone mineral density in Indian population. Clin Endocrinol (Oxf). 2014 Jan;80(1):41-6.

21 Angurana SK, Angurana RS, Mahajan G, Kumar N, Mahajan V. Prevalence of vitamin $D$ deficiency in apparently healthy children in north India. J Pediatr Endocrinol Metab. 2014 Nov;27(11-12):11516.

22 Cairncross CT, Stonehouse W, Conlon CA, Grant CC, McDonald B, Houghton LA, et al. Predictors of vitamin D status in New Zealand preschool children. Matern Child Nutr. 2017 Jul;13(3):e12340.

23 Lane G, Nisbet C, Whiting SJ, Vatanparast H. Canadian newcomer children's bone health and vitamin D status. Appl Physiol Nutr Metab. 2019 Jul;44(7):796-803.

24 Omand JA, Darling PB, Parkin PC, Birken CS, Khovratovich M, Thorpe KE, et al.; TARGet Kids! Collaboration. Non-Western immigrant children have lower 25-hydroxyvitamin D than children from Western families. Public Health Nutr. 2014 Jul;17(7):154754.

25 Ferguson JH, Chang AB. Vitamin D supplementation for cystic fibrosis. Cochrane Database Syst Rev. 2014 May;(5):CD007298.

26 Viraraghavan VR, Seth A, Aneja S, Singh R, Dhanwal D. Effect of high dose vitamin d supplementation on vitamin d nutrition status of pre-pubertal children on anti-epileptic drugs - A randomized controlled trial. Clin Nutr ESPEN. 2019 Feb;29:36-40.

27 Zakharova I, Klimov L, Kuryaninova V, Nikitina I, Malyavskaya S, Dolbnya S, et al. Vitamin D Insufficiency in Overweight and Obese Children and Adolescents. Front Endocrinol (Lausanne). 2019 Mar; 10:103. 
28 Sharif Y, Sadeghi O, Dorosty A, Siassi F, Jalali M, Djazayery A, et al. Serum Levels of Vitamin D, Retinol and Zinc in Relation to overweight among Toddlers: Findings from a National Study in Iran. Arch Iran Med. 2019 Apr;22(4):174-81.

29 Lewis RD, Laing EM. Conflicting reports on vitamin D supplementation: evidence from randomized controlled trials. Mol Cell Endocrinol. 2015 Jul;410:11-8.

30 Moon RJ, Davies JH, Cooper C, Harvey NC. Vitamin D, and Maternal and Child Health. Calcif Tissue Int. 2020 Jan;106(1):30-46.

31 Reinehr T, Schnabel D, Wabitsch M, Bechtold-Dalla Pozza S, Bührer $C$, Heidtmann B, et al. Vitamin D supplementation after the second year of life: joint position of the Committee on Nutrition, German Society for Pediatric and Adolescent Medicine (DGKJ e.V.), and the German Society for Pediatric Endocrinology and Diabetology (DGKED e.V.). Mol Cell Pediatr. 2019 May;6(1):3.

32 Hill TR, Cotter AA, Mitchell S, Boreham CA, Dubitzky W, Murray L, et al. Vitamin D status and its determinants in adolescents from the Northern Ireland Young Hearts 2000 cohort. Br J Nutr. 2008 May;99(5):1061-7.

33 Bailey DA, Martin AD, McKay HA, Whiting S, Mirwald R. Calcium accretion in girls and boys during puberty: a longitudinal analysis. J Bone Miner Res. 2000 Nov;15(11):2245-50.

34 Andersen R, Mølgaard C, Skovgaard LT, Brot C, Cashman KD, Jakobsen J, et al. Effect of vitamin D supplementation on bone and vitamin D status among Pakistani immigrants in Denmark: a randomised double-blinded placebo-controlled intervention study. Br J Nutr. 2008 Jul;100(1):197-207.

35 Cheng S, Lyytikäinen A, Kröger H, Lamberg-Allardt C, Alén M, Koistinen A, et al. Effects of calcium, dairy product, and vitamin D supplementation on bone mass accrual and body composition in 10-12-y-old girls: a 2-y randomized trial. Am J Clin Nutr. 2005 Nov; $82(5): 1115-26$

36 Du X, Zhu K, Trube A, Zhang Q, Ma G, Hu X, et al. School-milk intervention trial enhances growth and bone mineral accretion in Chinese girls aged 10-12 years in Beijing. Br J Nutr. 2004 Jul;92(1): 159-68.

37 El-Hajj Fuleihan G, Nabulsi M, Tamim H, Maalouf J, Salamoun M, Khalife $H$, et al. Effect of vitamin $D$ replacement on musculoskeletal parameters in school children: a randomized controlled trial. J Clin Endocrinol Metab. 2006 Feb; 91(2):405-12.

38 Viljakainen HT, Natri AM, Kärkkäinen M, Huttunen MM, Palssa A, Jakobsen $\mathrm{J}$, et al. A positive dose-response effect of vitamin D supplementation on site-specific bone mineral augmentation in adolescent girls: a double-blinded randomized placebo-controlled 1-year intervention. J Bone Miner Res. 2006 Jun;21(6): 836-44.

39 Al-Shaar L, Nabulsi M, Maalouf J, El-Rassi R, Vieth R, Beck TJ, et al. Effect of vitamin $D$ replacement on hip structural geometry in adolescents: a randomized controlled trial. Bone. 2013 Oct;56(2): 296-303.

40 Khadilkar AV, Sayyad MG, Sanwalka NJ, Bhandari DR, Naik S, Khadilkar VV, et al. Vitamin D supplementation and bone mass accrual in underprivileged adolescent Indian girls. Asia Pac J Clin Nutr. 2010;19(4):465-72.
41 Mølgaard C, Larnkjaer A, Cashman KD, Lamberg-Allardt C, Jakobsen J, Michaelsen KF. Does vitamin D supplementation of healthy Danish Caucasian girls affect bone turnover and bone mineralization? Bone. 2010 Feb; 46(2):432-9.

42 Ward KA, Das G, Roberts SA, Berry JL, Adams JE, Rawer R, et al. A randomized, controlled trial of vitamin $\mathrm{D}$ supplementation upon musculoskeletal health in postmenarchal females. J Clin Endocrinol Metab. 2010 Oct; 95(10):4643-51.

43 Winzenberg TM, Powell S, Shaw KA, Jones G. Vitamin D supplementation for improving bone mineral density in children. Cochrane Database Syst Rev. 2010 Oct;(10):CD006944.

44 Winzenberg T, Powell S, Shaw KA, Jones G. Effects of vitamin D supplementation on bone density in healthy children: systematic review and meta-analysis. BMJ. 2011 Jan;342:c7254.

45 Joo NS, Dawson-Hughes B, Yeum KJ. 25-Hydroxyvitamin D, calcium intake, and bone mineral content in adolescents and young adults: analysis of the fourth and fifth Korea National Health and Nutrition Examination Survey (KNHANES IV-2, 3, 2008-2009 and V-1, 2010). J Clin Endocrinol Metab. 2013 Sep;98(9):3627-36.

46 Rajakumar K, Fernstrom JD, Janosky JE, Greenspan SL. Vitamin D insufficiency in preadolescent African-American children. Clin Pediatr (Phila). 2005 Oct;44(8):683-92.

47 Houghton LA, Szymlek-Gay EA, Gray AR, Ferguson EL, Deng X, Heath AL. Predictors of vitamin D status and its association with parathyroid hormone in young New Zealand children. Am J Clin Nutr. 2010 Jul; 92(1):69-76.

48 Atapattu N, Shaw N, Högler W. Relationship between serum 25-hydroxyvitamin $D$ and parathyroid hormone in the search for a biochemical definition of vitamin D deficiency in children. Pediatr Res. 2013 Nov;74(5):552-6.

49 Uday S, Högler W. Spot the silent sufferers: A call for clinical diagnostic criteria for solar and nutritional osteomalacia. J Steroid Biochem Mol Biol. 2019 Apr;188:141-6.

50 Ceroni D, Anderson de la Llana R, Martin X, Lamah L, De Coulon $G$, Turcot K, et al. Prevalence of vitamin D insufficiency in Swiss teenagers with appendicular fractures: a prospective study of 100 cases. J Child Orthop. 2012 Dec;6(6):497-503.

51 Ryan LM, Teach SJ, Singer SA, Wood R, Freishtat R, Wright JL, et al. Bone mineral density and vitamin $D$ status among African American children with forearm fractures. Pediatrics. 2012 Sep; 130(3):e553-60.

52 Anderson LN, Heong SW, Chen Y, Thorpe KE, Adeli K, Howard A, et al.; TARGet Kids Collaboration. Vitamin D and Fracture Risk in Early Childhood: A Case-Control Study. Am J Epidemiol. 2017 Jun;185(12):1255-62.

53 Servaes S, States L, Wood J, Schilling S, Christian CW. Rachitic change and vitamin $D$ status in young children with fractures. Skeletal Radiol. 2020 Jan;49(1):85-91.

54 Chapman T, Sugar N, Done S, Marasigan J, Wambold N, Feldman $K$. Fractures in infants and toddlers with rickets. Pediatr Radiol. 2010 Jul; 40(7):1184-9.

55 Kepron C, Pollanen MS. Rickets or abuse? A histologic comparison of rickets and child abuse-related fractures. Forensic Sci Med Pathol. 2015 Mar;11(1):78-87. 
56 Cannell JJ, Holick MF. Multiple unexplained fractures in infants and child physical abuse. J Steroid Biochem Mol Biol. 2018 Jan; $175: 18-22$

57 Miller M, Stolfi A, Ayoub D. Findings of metabolic bone disease in infants with unexplained fractures in contested child abuse investigations: a case series of 75 infants. J Pediatr Endocrinol Metab. 2019 Oct;32(10):1103-20.

58 Zipitis CS, Akobeng AK. Vitamin D supplementation in early childhood and risk of type 1 diabetes: a systematic review and metaanalysis. Arch Dis Child. 2008 Jun; 93(6):512-7.

59 Jolliffe DA, Greenberg L, Hooper RL, Griffiths CJ, Camargo CA Jr, Kerley $C P$, et al. Vitamin $D$ supplementation to prevent asthma exacerbations: a systematic review and meta-analysis of individual participant data. Lancet Respir Med. 2017 Nov;5(11):881-90.

60 Hattangdi-Haridas SR, Lanham-New SA, Wong WH, Ho MH, Darling AL. Vitamin D Deficiency and Effects of Vitamin D Supplementation on Disease Severity in Patients with Atopic Dermatitis: A Systematic Review and Meta-Analysis in Adults and Children. Nutrients. 2019 Aug;11(8):E1854

61 Martineau AR, Jolliffe DA, Greenberg L, Aloia JF, Bergman P, Dubnov-Raz G, et al. Vitamin D supplementation to prevent acute respiratory infections: individual participant data meta-analysis. Health Technol Assess. 2019 Jan;23(2):1-44.

62 Singh N, Kamble D, Mahantshetti NS. Effect of Vitamin D Supplementation in the Prevention of Recurrent Pneumonia in UnderFive Children. Indian J Pediatr. 2019 Dec;86(12):1105-11.

63 de la Hunty A, Wallace AM, Gibson S, Viljakainen H, Lamberg-Allardt C, Ashwell M. UK Food Standards Agency Workshop Consensus Report: the choice of method for measuring 25-hydroxyvitamin D to estimate vitamin D status for the UK National Diet and Nutrition Survey. Br J Nutr. 2010 Aug;104(4):612-9.
64 Newton DA, Baatz JE, Kindy MS, Gattoni-Celli S, Shary JR, Hollis $B W$, et al. Vitamin D binding protein polymorphisms significantly impact vitamin D status in children. Pediatr Res. 2019;86(5):6629.

65 Davis RL, Aksornsri A, Papachrisanthou MM, Vitamin D. Screening Variations in Children and Adolescents: who should be Screened? J Pediatr Nurs. 2019 Mar-Apr;45:57-61.

66 LeFevre ML; U.S. Preventive Services Task Force. Screening for vitamin D deficiency in adults: U.S. Preventive Services Task Force recommendation statement. Ann Intern Med. 2015 Jan;162(2): $133-40$.

67 Chouraqui JP, Tavoularis G, Turck D, Ferry C, Feillet F. Mineral and vitamin intake of infants and young children: the Nutri-Bébé 2013 survey. Eur J Nutr. 2019, Epub ahead of print.

68 Eldridge AL, Catellier DJ, Hampton JC, Dwyer JT, Bailey RL. Trends in Mean Nutrient Intakes of US Infants, Toddlers, and Young Children from 3 Feeding Infants and Toddlers Studies (FITS). J Nutr. 2019 Jul;149(7):1230-7

69 Day RE, Krishnarao R, Sahota P, Christian MS. We still don't know that our children need vitamin D daily: a study of parents' understanding of vitamin $D$ requirements in children aged 0-2 years. BMC Public Health. 2019 Aug;19(1):1119.

70 Waheed N, Cheema HA, Saeed A, Alvi MA, Fayyaz Z, Anjum N, et al. Vitamin D Intoxication In 7-Month-Old Infant With Recommended Daily Intake Of Vitamin D. J Ayub Med Coll Abbottabad. 2018 Oct-Dec;30(Suppl 1)(4):S673-5. 